\title{
Zaplňování bílých míst konce války: Zpráva o nedávné výstavě v semilském muzeu
}

Tomáš Chvátal

\section{Filling Out Blank Spaces of the World War II Final Stages: Report on the Semily Museum Recent Exhibition}

\begin{abstract}
Výstava Bílá místa konce války (1944-5) s podtitulem Válečná výroba a nucené nasazení v Semilech probíhala v semilském muzeu od 17. 7. 2020 do 25. 7. 2021. Byla jedním z našich nejobsáhlejších výstavních projektů, který byl navíc oceněn v soutěži Gloria Musaealis III. cenou v kategorii Výstava roku 2020. Toto ocenění vnímáme mimo jiné jako vzpruhu pro malá muzea, že i v malých poměrech, s omezenými prostředky a malým realizačním týmem se dají dělat velké věci. Proto bychom rádi tuto výstavu v následujícím článku blíže představili.
\end{abstract}

\section{Úvodní představení}

Muzeum a Pojizerská galerie Semily, p. o. je malým regionálním muzeem zřizovaným městem Semily. Sídlí v nevelkých prostorách bývalého měštanského domu v Husově ulici čp. 2. Ač první snahy o zřízení této instituce a budování sbírek sahají už do konce devatenáctého století, muzeum coby svébytná organizace se stálými výstavními prostory vzniklo až $\mathrm{v}$ roce 1960. Původní název Muzeum dělnického hnutí a Památník Antala Staška a Ivana Olbrachta dává tušit, že budování sbírek a expozic bylo až do roku 1989 ideologicky velmi zatížené. Po sametové revoluci byla vybudována $\mathrm{v}$ prvním patře muzea nová stálá expozice nazvaná Osobnosti Semilska, i ta však časem svým pojetím zastarala. V současné době je jedinou trvalejší expozicí podstřešní Tajemství řemesel našich předků, zbylé čtyři výstavní prostory muzea slouží ke krátkodobým či střednědobým výstavám. Současnou snahou muzea je stát se přitažlivým kulturním a vzdělávacím centrem, což se ve výstavní rovině projevuje také pořádáním výpravných výstav zaměřených na zajímavá témata regionální historie, jež mají potenciál oslovit i celorepublikové publikum.

\section{Připrava}

Jedním z opomenutých témat byla v Semilech válečná výroba ve zdejším podniku Zittwerke - a s tím spjatá problematika nuceného nasazení českých chlapců a dívek a jejich životních podmínek. Na počátku projektu stály nejasné zvěsti, které kolovaly městem: že zde prý na konci války existovala jakási tajná výroba pro nacistické Německo, že se zde vyráběly letecké motory, a dokonce i Hitlerovy „,tajné zbraně" - raketové střely V-1 a V-2. Ty se zde údajně také zkoušely a řev jejich motorů byl slyšet až do Koštálova a Lomnice nad Popelkou. Bližších informací však bylo pomálu. Proto jsme se v roce 2018 rozhodli toto téma podrobně probádat a představit ho následně veřejnosti.

Badatelská příprava trvala nakonec celé dva roky. Postupně se podařilo shromáždit rozeseté informace a písemné dokumenty bývalé firmy Zittwerke, a to jak v archivech (SOkA Semily, SOA Zámrsk, Landesarchiv Sachsen-Anhalt Dessau), tak také mezi obyvateli města a okolí.

Dalším úkolem bylo naučit se takto shromážděné dokumenty číst s porozuměním - nešlo jen o převažující němčinu, ale především o to, že se jednalo většinou o fragmenty výrobní a účetní dokumentace, hemžící se odbornými výrazy a výrobními čísly jednotlivých dílů. S tím, jak jsme toto specifické názvosloví začali ovládat, objevovaly se stále více kontury semilské válečné výroby, náležející ke koncernu Junkers. Začalo být patrné, že se zde vyráběly a opravovaly jak klasické vrtulové motory Jumo 211 a 213, tak i první proudové motory Jumo 004. Právě druhé zmíněné způsobovaly hluk, který přesahoval hranice města samotného. Výsledkem tak bylo vyvrácení hypotézy o výrobě V-2, na druhou stranu se podařilo přesně definovat činnost semilského tajného oddělení
PhDr. Tomáš Chvátal, PhD Muzeum a Pojizerská galerie Semily historik@muzeumsemily.cz 
v podobě výroby a oprav jen o málo méně tajných prvních proudových motorů.

Zároveň při procházení archivních pramenů rostly i naše vědomosti o konkrétních lokalitách spjatých se semilskou válečnou výrobou. Původní zvěsti hovořily jen o jedné či dvou zapojených továrnách, nakonec se ale zapojení do činnosti Zittwerke prokázalo u celých šesti továrních budov v Semilech a Benešově u Semil. Podobně tomu bylo i s ubytovacími prostory, kdy jsme nalezli 32 konkrétních firemních ubytoven (hostinců, zrušených sokoloven, vystěhovaných škol, ale třeba i dvou nově postavených barákových táborů s kapacitou 2 x 1.000 lidí), nacházejících se v Semilech, Bítouchově, Chuchelně, Benešově u Semil, Podbozkově a Libštátě. V této době jsme začali vnímat, jak se konkrétními vědomostmi začínají zaplňovat četná bílá místa konce války v našem kraji - a tak také vznikl název výstavy.

Co se vzpomínek přímých účastníků a pracovníků týče, vypadalo to, že jsme začali př́liš pozdě. Matematika se zdála být neúprosná: na začátku našeho pátrání uplynulo už celých 73 let po konci války, přičemž nejmladším pracovníkům nuceně nasazených $\mathrm{v}$ semilském Zittwerke bylo tehdy sedmnáct let. Zdálo se tedy velmi nepravděpodobné, že se nám podaří nějakého žijícího pamětníka ještě nalézt. Velkým přínosem proto pro nás byla ochotná spolupráce Česko-německého fondu budoucnosti, který v letech 20002006 organizoval odškodňování nuceně nasazených Čechů. $\mathrm{V}$ rámci této akce se přihlásilo také téměř osm set osob, které prošly Semily. Mnozí z nich připojili i písemné vzpomínky či fotografie, jež byly díky ochotě pracovníků fondu po náležitém anonymizování poskytnuty pro účely tohoto projektu. Semilské události tak dostaly mnohem konkrétnější podobu a osobní rozměr. Ten se na výstavě podařilo umocnit jmenným soupisem téměř tří tisíc pracovníků semilského Zittwerke 2.330 Čechů a 625 Němců, jejichž jména jsme nalezli především v tzv. policejních přihláškách přechodného pobytu (jde odhadem o $75 \%$ celkového stavu zaměstnanců, část především místních lidí do policejních přihlášek zahrnuta nebyla). Další splněný sen se týkal fotografií z továrny: původně jsme se smířili s tím, že vzhledem k utajení výroby jistě nebylo $\mathrm{v}$ provozech možno fotit. $\mathrm{O}$ to více jsme byli překvapeni, když jsme při pátrání ve fondu firmy Sochor Dvưr Králové nad Labem, v jejímž areálu byla umístěna sesterská pobočka Junkersu, nalezli rozsáhlé firemní album několika stovek snímků přímo z výroby dílů pro letecké motory. Tyto fotografie se daly výborně vztáhnout i na Semily, zvětšené na kappa deskách nám pak na výstavě utvořily živou iluzi pulzujícího továrního provozu.

Rozhodili jsme také sítě mezi známými i měně známými občany Semil a okolí ohledně dochovaných pozůstatků válečné výroby. Tak byl nalezen například originální válečný plán celých Semil a Benešova s vyznačenými továrnami a ubytovacími kapacitami Zittwerke či další plán s tajnými zkušebnami proudových motorů. Mezi občany jsme nalezli také části vyráběných motorů, krycí plechy a nádrže, elektrické př́istroje, dílenské příručky a další exponáty a podařilo se vyjednat jejich zapưjčení na budoucí výstavu.

\section{Koncepce}

Nastávala doba k vypracování samotného expozičního konceptu. Díky dobrým zkušenostem s předchozím projektem Plíživá kontrarevoluce v Semilech 1968, který zpracovával události kolem zdejšího Klubu mladých, jsme se rozhodli téma pojmout opět trojím způsobem: jako výstavu, knihu a dokumentární film. Naším cílem bylo, aby každé médium představilo téma svým specifickým způsobem. U výstavy jsme se především snažili návštěvníka co nejvíce vtáhnout do děje pomocí velkoformátových fotografií, originálních artefaktů a dioramat zobrazujících život nuceně nasazených, práci v továrně či úprk německé armády ze Semil v květnu roku 1945. Dokumentární film pak měl být založený na unikátních výpovědích pamětníků (plánovali jsme nechat profesionálními herci přemluvit vzpomínky 

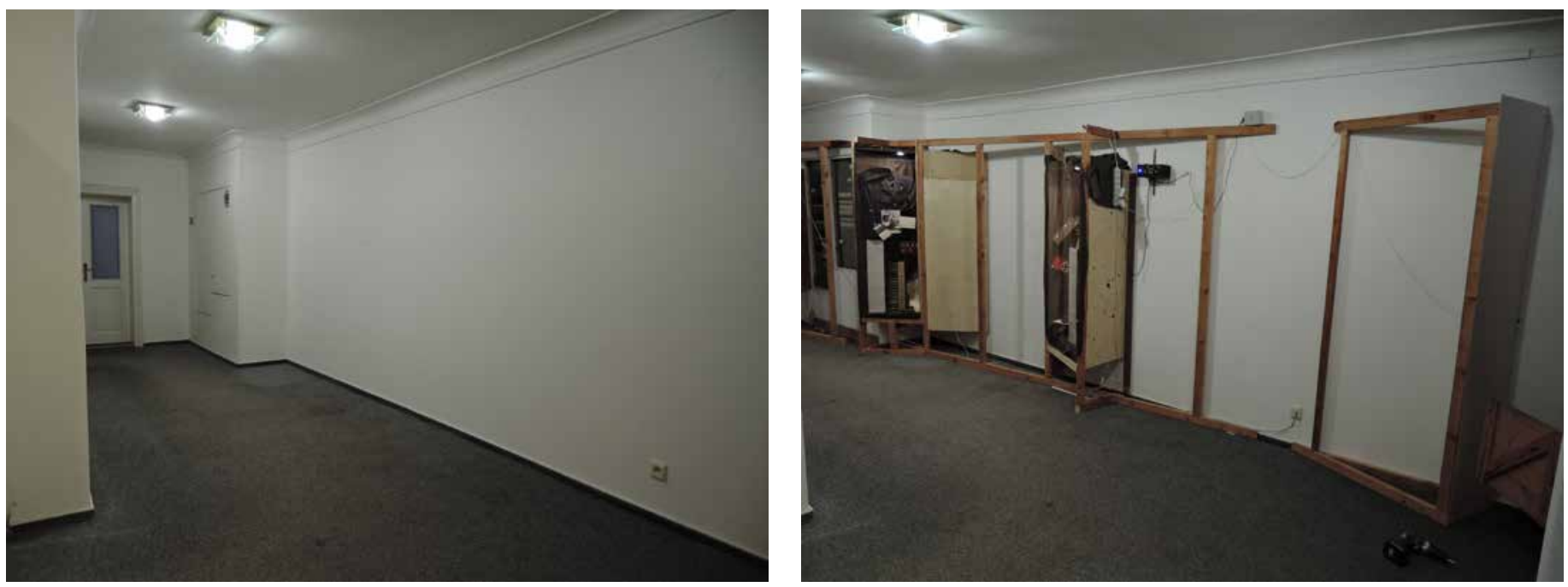

z Fondu budoucnosti), na záběrech ze současné továrny, dobových fotografiích, 3D modelu zaniklého barákového tábora atd. Kniha vydaná v muzejní edici Pamět Semilska pak měla umožnit podrobnější zpracování tématu včetně četných fotografií a bibliografických odkazů.

Takto rozkročený projekt samozřejmě nebylo možno zvládnout vlastními finančními prostředky. Velkou vzpruhou nám zde byla udělená záštita ministra kultury ČR PhDr. Lubomíra Zaorálka a finanční grant MK ČR, který za přispění města Semily pokryl náklady na vznik výstavy a filmu. Kniha pak byla financována $\mathrm{v}$ rámci muzejní ediční řady Pamět' Semilska, podporované taktéž městem Semily.

Pro historické střednědobé výstavy jsou $\mathrm{v}$ našem muzeu k dispozici prostory v prvním patře. Jedná se o místnosti, které nezapřou svůj původní účel v podobě ubytování měštanské rodiny. Konkrétně jde o nepříliš širokou střední chodbu, na kterou navazují dva polokruhy o čtyřech místnostech. Většina prostor je zde poměrně malá (kolem $12 \mathrm{~m}^{2}$ ), pouze jeden čtvercový sál má plochu $45 \mathrm{~m}^{2}$. Dalším omezujícím faktorem bylo velké množství oken, které zmenšují výstavní plochu stěn a zároveň oslabují případný efekt vtažení do tématu. Počítat bylo třeba také s vertikálními, ke stěnám napevno přisazenými vitrínami ze sádrokartonu (1-2 kusy v každé místnosti).

\section{Realizace}

Při této výstavě jsme využili přibližně dvě třetiny prvního patra, přičemž jsme se rozhodli narušit klasické kruhové rozvržení expozice. Z úvodní místnosti se vstupovalo do menšího prostoru,



nazvaného Junkers a Semily. Odtud vedly jednak dveře do uzavřené místnosti Život $v$ Zittwerke s dioramatem barákového tábora, ale také do Továrny s představenou válečnou výrobou, z níž se dále postupovalo do Květnových událostí na Semilsku a do místnosti s poválečným vývojem, kde prohlídka končila a bylo možno projít opět na začátek. Efektem, kterého si všimli opakovaně i jednotliví návštěvníci, bylo psychologické rozšírení místností v prvním patře.

S grafikou velkých panelů a plakátu nám pomáhal externí grafik, externě byl profesionálním architektonickým studiem vytvořen také 3D plán bývalého tábora U Čtrnácti pomocníků. Jinak probíhala realizace $\mathrm{v}$ podstatě $\mathrm{v}$ jednom člověku, spojujícím funkce autora libreta, pomocného grafika, zajištovatele zápůjček i realizátora samotné expozice.
Postupná proměna úvodní místnosti výstavy 

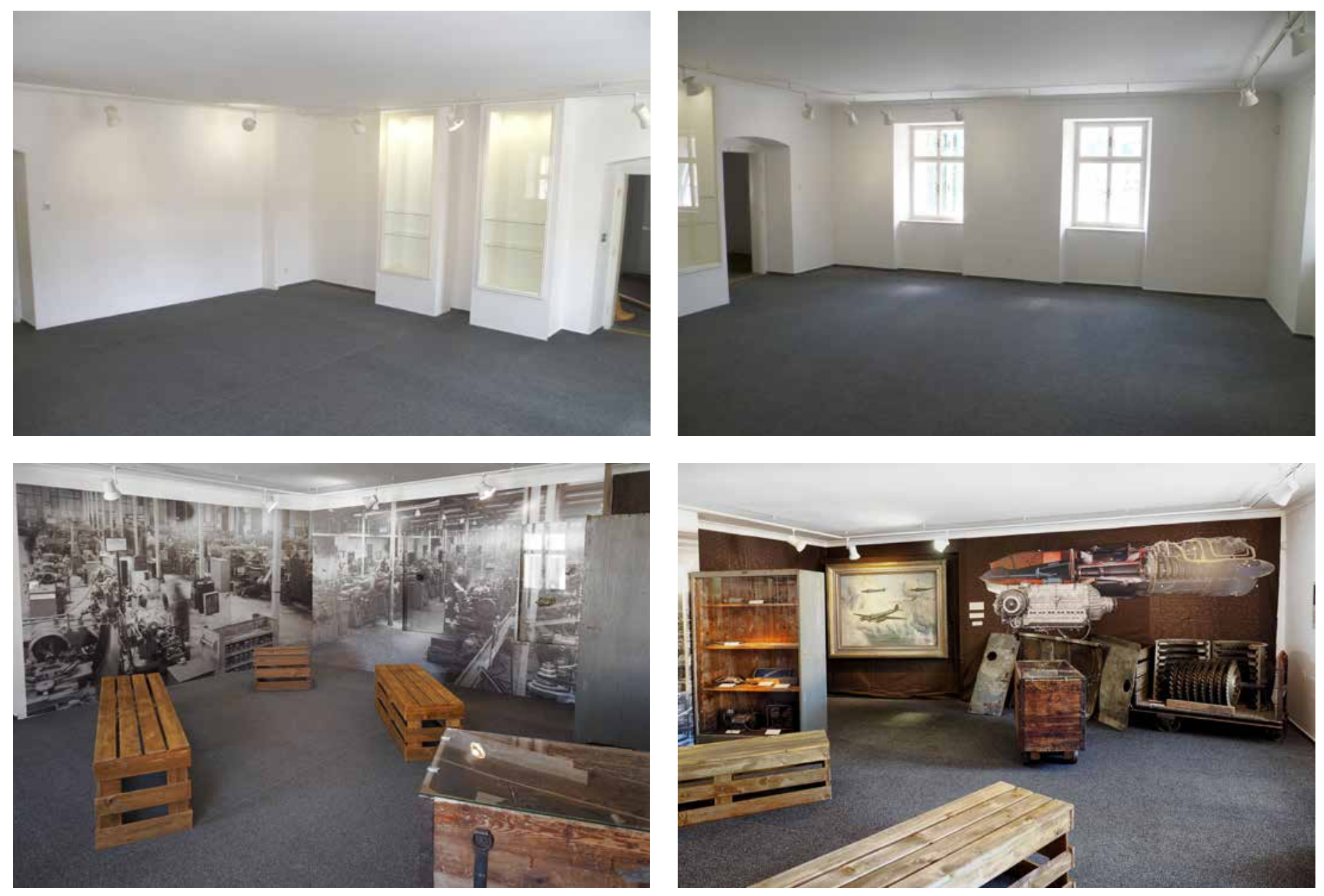

Tovární místnost: stav před instalací a po ní
V následujícím textu bychom rádi představili několik prostorových řešení v rámci výstavy.

\section{Úvod do výstavy}

Dosud příliš nevyužívaná vstupní chodba hostila úvod do válečných událostí, který na základě fotografií i originálních artefaktů přibližoval vývoj války ve světě i ve městě a zároveň byl i prologem k tématu válečné výroby. Základním prvkem byly tři velkoformátové fotografie, uvozující témata Nástup nacismu (Hitler řečnící $\mathrm{k}$ davu), Expanze (tank Panther při útoku na východní frontě) a Počátek konce (vybombardované Drážd’any). Návštěvníka při vstupu na výstavu uvítal nejen pohled na nacistický sjezd, ale také zvuk (z minipočítače Raspberry s fotobuňkou), který všechna tato tři témata propojoval.

Velkoplošné fotografie vždy doprovázela krátká textová charakteristika daného období, ve vestavěné vitríně pak byly vystaveny originální artefakty, které dané téma doplňovaly z hlediska lokálních dějin: u prvního okruhu to byl např́iklad mundưr politického vězně z koncentračního tábora či průkazka Hitlerjugend, u druhého doklady semilského domácího i zahraničního odboje (uniforma RAF, časopis V Boj), u třetího pak příručky protiletecké obrany a kniha náletů města Semil. Vše bylo na druhé stěně doplněno plakátovací plochou s dobovými nacistickými vyhláškami. Omezení dané zužujícím se prostorem nám zde paradoxně pomohlo ve vytváření dojmu, jak se nacisté s postupem války „dostávali do úzkých". Snímek vybombardovaného německého města pak bezprostředně uvedl další téma, tedy vznik pobočky Junkersu v Semilech.

\section{Továrna}

Při budování „ztemnělé“ atmosféry místa bylo pro nás důležitá otázka, jak jednoduchým a lehce demontovatelným způsobem potlačit množství okenních otvorů a zároveň bez nutnosti malování změnit pro výstavu nevhodnou bělost stěn. Jako ideální a přitom velmi levné řešení se ukázala netkaná textilie pro zahrádkářství, dostupná ve velkých rozměrech $v$ tmavě hnědé barvě. Tu jsme na zed' přichycovali na stranách hřebíčky.

Dojem autenticity byl podpořen zapůjčením skříně a továrních vozíků přímo 
z bývalého areálu Zittwerke. Pro sezení školních skupin pro skupinovou práci i zhlédnutí dokumentárního filmu byly vytvořeny autenticky působící prkenné bedny, které v sobě skrývaly vždy druhou, menší a po rozložení umožňovaly posezení přibližně pro dvacet lidí. Dvě sádrokartonové vestavěné vitríny byly „zneviditelněny" vložením fotografie, díky tomu mohly být využity jako nerušivá součást panorámatu továrny (byla v nich umístěna čerpadla, která sjížděla na tovární pás). Atmosféru i zde doplňovala audio plocha se zvuky kovozpracující továrny (bylo ji možno vypnout, např́klad během komentované prohlídky).

\section{Koronavirové změny a hledání nových cest}

Náš původní plán počítal s tím, že výsta$\mathrm{vu}$, knihu i film spustíme na oslavu tři čtvrtě století konce války ve stejný okamžik, $\mathrm{v}$ prvních květnových dnech roku 2020. Tyto plány zcela rozbourala první koronavirová uzávěra: $\mathrm{v}$ původním termínu jsme nakonec $\mathrm{v}$ omezeném počtu, bez účasti veřejnosti, pokřtili pouze knihu. Vernisáž výstavy proběhla až 17. července 2020, premiéra filmu pak těsně před další uzávěrou, 30. září 2020.

Koronavirové změny byly samozřejmě nemilé, na výslednou podobu projektu měly ale i některé pozitivní efekty: Vydání knihy totiž do našeho muzea přivedlo i některé další zapůjčitele exponátů pro výstavu. Díky distribuční síti Kosmas si ji mohli zakoupit i lidé mimo Semily - a tak se dostala (jako dar od vnuka) i k dvaadevadesátileté paní Síbrové z Rudníku, která v Zittwerke sama pracovala, a to dokonce $\mathrm{v}$ takzvaném tajném oddělení. Díky tomu, že pamětnice naše muzeum následně kontaktovala, se pak její svědectví mohlo stát jedním z pilírù dokumentárního filmu. Další důležitý svědek se objevil mezi návštěvníky výstavy. Pan Vodsedálek pak ve filmu živě zavzpomínal na to, jak jako malí kluci s kamarády na ostrohu továrny $\mathrm{v}$ Řekách pozorovali zkoušky proudových motorů. Výstava byla nakonec kvůli koronavirovým peripetiím prodloužena na dobu

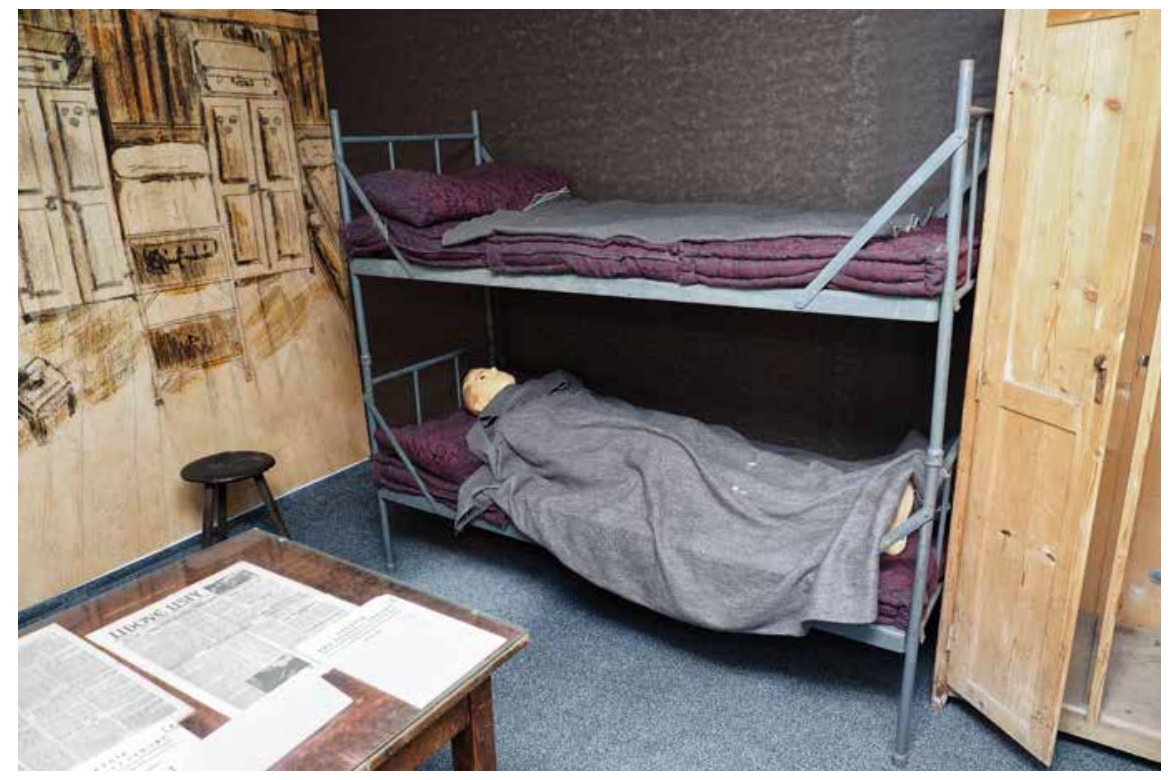

trvání jeden rok, návštěvníci ji ale mohli zhlédnout jen přibližně polovinu této doby, kdy muzeum nebylo $z$ důvodu vládních opatření uzavřeno. I přes složitou dobu a různá další omezení výstavu za toto období zhlédlo 3626 návštěvníků. Radost máme z toho, že mnozí z nich mířili cíleně na tuto výstavu a že se často jednalo o lidi, kteř́ jinak muzeum nenavštěvují. Potěšitelná je i bilance návštěvy školních skupin - program dlouhý 90 minut absolvovalo 621 žáků a studentů od 7. třídy ZŠ po maturanty, což představuje naprostou většinu osazenstva škol v Semilech a blízkém okolí.

Tím však návštěvnické statistiky nekončí: dokumentární film, který jsme v říinu 2020 umístili na platformu Youtube, má na konci srpna 2021 přes 20 tisíc unikátních diváků. Navíc film přijala i Česká televize $\mathrm{s}$ tím, že jej bude $\mathrm{v}$ následujících letech opakovaně vysílat, počet diváků bude tedy rapidně stoupat. Výstavu se podařilo opakovaně prezentovat $\mathrm{v}$ médiích např́íklad v novinách Mladá Fronta Dnes či Deník. Celkem třikrát se pak objevila ve vysílání České televize, nejrozsáhleji jako součást prestižního pořadu Historie. cs nazvaného Ročníky totálního nasazení (premiéra 23. 1. 2021). Celostátní pozornost přinesla také účast $\mathrm{v}$ soutěži Gloria musaealis, kdy se v konkurenci mnohem větších projektů s rozsáhlejšími rozpočty a realizačními týmy podařilo získat 3 . místo v kategorii Výstava roku 2020.

Zároveň se díky grantu Ministerstva kultury podařilo uchovat výstavu i po její deinstalaci v podobě virtuální prohlídky, kterou lze zhlédnout na adrese https://
Další realizace na výstavě: rekonstrukce mistnosti v barákovém táboře 


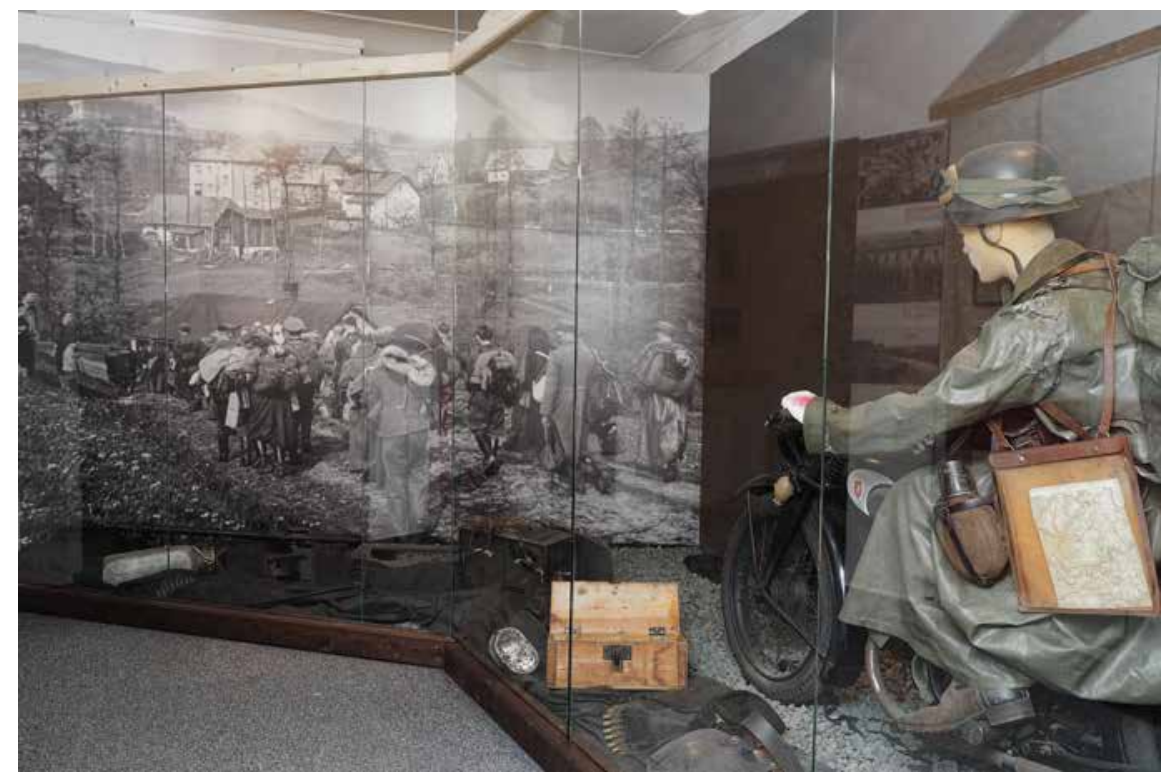

Panorama útěku německé armády ze Semil www.muzeumsemily.cz/vp/bila-mista-konce-valky/. Jedná se o první virtuální prohlídku v našem muzeu. Návštěvník má zde možnost procházet se jednotlivými místnostmi, přibližovat si detaily, rozkrývat popisky předmětů či fotogalerie, atmosféru na dvou místech doplňuje také zvuková kulisa. Zároveň lze přímo ve virtuální expozici zhlédnout také stejnojmenný dokumentární film. Virtuální podoba umožnila zapracovat dokonce i ty exponáty, které byly nalezeny teprve nedávno a na fyzické výstavě nebyly vystaveny. Takto lze např́iklad u turbíny z motoru Jumo 004 nalézt zkorodovanou lopatku tohoto motoru, kterou se nám úplnou náhodou podařilo $\mathrm{v}$ lednu tohoto roku nalézt při rodinné vycházce na soutoku Kamenice a Vošmendy. Tento virtuální exponát je připomínkou toho, že se tajné proudové motory nemontovaly jen v Semilech, ale např́ḱklad i v Plavech a Smržovce.

Také samotná fyzická výstava bude žít alespoň částečně dále - díky iniciativě pana Josefa Jiránka a spolupráci s Městským muzeem ve Dvoře Králové nad Labem se většina exponátů i velkoformátových fotografií přesunula právě sem, aby zde od 17. 9. 2021 tvořila základ výstavy Bílá místa konce války ve Dvoře Králové nad Labem, která bude mapovat válečnou výrobu ve zdejší pobočce Junkersu. Máme radost, že tak naše výstava iniciovala pátrání po válečné výrobě v jiném městě, které se kromě výstavy samotné projeví i v nově vydané tematické brožuře.

Některé z vystavených exponátů se díky výstavě staly součástí muzejních sbírek. Kromě již jmenované lopatky z proudového Jumo 004 je to například originální šatní skřín nuceně nasazených z ubytovny Zittwerke v Chuchelně (nákup z internetu za 500 Kč), oběžné kolo z kompresoru motoru Jumo 211 (nalezeno autorem výstavy v semilských sběrných surovinách) či vícero darů: známka pracovníka Junkers Ausbildungswerke Benešov u Semil, nářad'ové známky Junkers, trubkový vozík na dopravu dílů Jumo 004 či foto mladíků a dívek před barákovým táborem U Čtrnácti pomocníků. Radost máme také ze zaslaných vzpomínek Marie Votočkové ze Semil, které doplňují obraz květnových dnů roku 1945.

Závěrem můžeme říci, že se naše představy o podobě výstavy a jejích cílech i přes nelehkou dobu do velké míry opravdu naplnily. Podařilo se zaplnit četná bílá místa týkající se válečné výroby v Semilech i konce války se všemi jeho nejednoznačnostmi, s tématem se seznámilo mnoho lidí ve městě i v celé republice. My v muzeu jsme si vyzkoušeli četné nové př́istupy, a to jak co se týče podoby expozice, tak i využití nových médií. Budeme rádi, pokud příklad výstavy Bílá místa konce války poslouží dalším městským a regionálním muzeím jako inspirace a vzpruha. Závěrem bychom rádi poděkovali všem, bez jejichž podpory bychom tuto výstavu nemohli uskutečnit - všem zapůjčitelům, lidem, kteří nám zprostředkovali informace, všemožně nás podporovali či kteří nám třeba drželi palce. Budeme se je snažit nezklamat i v budoucnu, například při odkrývání dalších semilských bílých míst, spjatých tentokrát $\mathrm{s}$ internací řeholníků v semilské nemocnici v padesátých letech $\mathrm{v}$ rámci komunistické Akce $\mathrm{K}$. 